\title{
Effect of Starvation-Refeeding Status on Cholesterol Metabolism in Rats Fed High-Cholesterol Diet
}

\author{
Reiko Inai $^{1}$, Tatsuhiro Matsuo ${ }^{2}$ \\ ${ }^{1}$ Department of Health and Nutritional Science, Nagoya Keizai University, Aichi, Japan; \\ ${ }^{2}$ Faculty of Agriculture, Kagawa University, Kagawa, Japan. \\ Email: matsuo@ag.kagawa-u.ac.jp
}

Received November $9^{\text {th }}, 2010$; revised January $3^{\text {rd }}, 2011$; accepted January $24^{\text {th }}, 2011$.

\begin{abstract}
The present study investigated the effect of starvation-refeeding status on cholesterol metabolism in rats fed a high-cholesterol diet or a cholesterol-free diet. Twenty male and 20 female Donryu rats (age 5 weeks) were fed a cholesterol-free diet for 14 days. Then the male and female rats were each divided into two groups: feeding and starvation-refeeding groups. The feeding groups were fed the experimental diet for 3 days, and the starvation-refeeding groups fasted for 2 days followed by 3 days of feeding. Half of each of groups was fed a cholesterol-free diet and the other half was fed a high-cholesterol diet. Starvation-refeeding significantly increased the plasma free cholesterol and $H D L$-cholesterol concentrations in both the high-cholesterol-diet-fed rats and the cholesterol-free-diet-fed rats. In the female rats, plasma total cholesterol and cholesteryl ester concentrations were significantly higher in the high-cholesterol groups than in the cholesterol-free groups, whereas TG concentration and total cholesterol/TG ratio were not significantly different among all of the groups. Liver total cholesterol and cholesteryl ester were significantly higher in the high-cholesterol groups than in the cholesterol-free groups in both male and female rats. These results suggest that starvation-refeeding affected cholesterol metabolism at least in part. The reactivity of the cholesterol metabolism may be different between male and female rats.
\end{abstract}

Keywords: Starvation-Refeeding, Cholesterol Metabolism, High-Cholesterol Diet, Rat

\section{Introduction}

Many studies have suggested that starvation reduces the activities of hepatic enzymes in animals and fishes [1-7]. Some of the largest decreases in activity occur in the NADP-linked dehydrogenases of the cytosol [3] and organelles [1,5]. However, short-term starvation and later refeeding (starvation-refeeding) is a technique widely used to increase hepatic lipogenesis (de novo synthesis of long-chain fatty acids). Szepesi and Berdanier [8] reported that the response to a 2-day period of starvation followed by a 2-day period of refeeding typically include an increase in liver lipid content and an increase or overshoot in the activities of hepatic enzymes concerned with lipogenesis. Moreover, Wurdeman et al. [9] and Berdanier and Shubeck [10] demonstrated that glucocorticoid and insulin are involved in the genesis of the enzyme overshoot response to starvation-refeeding, perhaps through an effect on de novo RNA synthesis.
Cholesterol, one of the lipids of physiological significance, as well as triacylglycerol (TG) or fatty acids, is present in tissues and in plasma lipoprotein either as free cholesterol or, in combination with long-chain fatty acids, as cholesteryl ester [11]. It is synthesized in many tissues from acetyl-CoA and is ultimately eliminated from the body in the bile as cholesterol or bile salts. Cholesterol is the precursor of all other steroids in the body such as glucocorticoid and sex hormones [11]. Cholesterol synthesis in the liver may be accelerated under an activated condition of hepatic lipogenesis because cholesterol and fatty acids are closely related in mammalian lipid metabolism [12].

In the present study, we investigated the effect of starvation-refeeding status on cholesterol metabolism in rats fed a diet with or without dietary cholesterol. Furthermore, we examined whether or not a difference was found in the response to starvation-refeeding between male and female rats. 


\section{Materials and Methods}

\subsection{Animals, Diets, and Experimental Design}

All the procedures involving the rats were approved by the Experimental Animal Care Committee of Kagawa University.

Twenty male and 20 female Donryu rats (age 5 weeks) were purchased from Japan SLC, Inc. (Shizuoka, Japan). All rats were housed individually at $22^{\circ} \mathrm{C} \pm 1{ }^{\circ} \mathrm{C}$ with light from 08:00 to 20:00 $\mathrm{h}$ and free access to water. Rats were fed CE-2, a commercial rodent diet (CLEA, Tokyo, Japan) ad libitum until 6 weeks old. Rats were fed a synthetic diet containing the following ingredients, in grams per kilogram: casein, 250; $\alpha$-potato starch, 440; corn oil, 200; vitamin mixture [13], 8.5; mineral mixture [13], 50; choline chloride, 1.5; and cellulose 50. This diet also contained per $\mathrm{kg}$ : retinyl palmitate, 60,000 IU; ergocalciferol, $600 \mathrm{IU}$; $\alpha$-tocopheryl acetate, $1 \mathrm{~g}$. After a 14-day feeding period, the male and female rats were each divided into two groups: feeding and starvation-refeeding groups. The feeding group was fed the experimental diet for 3 days, and the starvation-refeeding group fasted for 2 days followed by 3 days of feeding. Half of each of these groups was fed the experimental diet (cholesterol-free diet), and the other half was fed a diet to which $1 \%$ cholesterol and $0.25 \%$ gall powder were added (high-cholesterol diet). After the feeding or starvation-refeeding period, rats were killed by heart puncturing under anaesthesia. Blood was collected to obtain plasma, and the liver was quickly removed, weighed, and stored at $-40^{\circ} \mathrm{C}$.

\subsection{Analysis}

The plasma total cholesterol, free cholesterol, HDL cholesterol and TG concentrations were determined using kits (Cholesterol E-Test, Free Cholesterol E-Test, HDL-Cholesterol E-Test and Triglyceride E-Test, Wako Pure Chemical Industries, Osaka, Japan). Plasma cholesteryl ester concentration was calculated from the plasma total cholesterol and free cholesterol concentrations. Total liver lipid and plasma lipid were extracted by the method of Folch et al. [14]. Liver total cholesterol, free cholesterol and cholesteryl ester contents were determined by the method previously described $[15,16]$. Plasma cholesteryl ester was divided using a thin-layer chromatography technique [17]. The fatty acid composition of plasma cholesteryl ester was determined using gas chromatography. The TG extract liquid was vaporized by nitrogen gas and then transmethylated using methanol-sulfuric acid (230:2, v/v). The fatty acid methyl esters were extracted with hexane and separated in a gas chromatograph (ModelG-163, Hitachi Co., Tokyo, Japan) equipped with a $3 \mathrm{~mm} \times 2 \mathrm{~m}$ glass column which filled up packing material (EGSS-Y, Shinwa Chemical Industries, Ltd., Tokyo, Japan). The column temperature was set at $187^{\circ} \mathrm{C}$. The carrier gas was helium at a flow rate of $40 \mathrm{ml} \cdot \mathrm{min}^{-1}$. Methyl esters of individual fatty acids were identified in the chromatograms by comparing their retention times to those of pure methyl esters, and were quantified by comparing the areas under their peaks.

\subsection{StatisticalAnalysis}

The values are expressed as means \pm standard deviation (SD). Data were evaluated by two-way ANOVA and Turkey's test was used to determine specific mean differences. A $p$ value of $<0.05$ was considered to show statistical significance. All analyses were performed with a commercially available statistical package (Excel Statistics, SSRI Co., Ltd., Tokyo, Japan).

\section{Results}

\subsection{Food Intake, Body Weight and Liver Weights}

Table 1 shows the food intake, body and liver weight. The food intakes of male and female rats were significantly higher in the starvation-refeeding groups than in the feeding groups regardless of the additional dietary cholesterol. No significant differences were found in the final body weight and relative liver weight in either male or female rats. In the female rats, the liver weight was higher in the high-cholesterol groups than in the cholesterol-free groups.

\subsection{Plasma Substrates}

Table 2 shows the plasma cholesterol and TG concentrations. In the male rats, no significant differences were found in the concentrations of plasma total cholesterol, cholesteryl ester, or TG, nor in the total cholesterol/TG ratio. Starvation-refeeding significantly increased the plasma free cholesterol and HDL-cholesterol concentrations in both the high-cholesterol-diet-fed rats and the cholesterol-free-diet-fed rats. The high-cholesterol diet caused the plasma HDL-cholesterol concentration to decrease significantly regardless of feeding status. In the female rats, plasma total cholesterol and cholesteryl ester concentrations were significantly higher in the highcholesterol groups than in the cholesterol-free groups, whereas TG concentration and total cholesterol/TG ratio did not differ significantly among any of the groups. The high-cholesterol diet caused a significant decrease in the plasma HDL-cholesterol and a significant increase in the non-HDL cholesterol concentrations. The plasma free cholesterol concentration was increased in the starvation-refeeding groups than in the feeding groups. 
Table 1. Effect of starvation-refeeding status on food intake, body and liver weights in high-cholesterol-diet-fed rats.

\begin{tabular}{|c|c|c|c|c|c|c|}
\hline & \multicolumn{2}{|c|}{ Groups } & \multirow{2}{*}{$\begin{array}{c}\text { Food intake } \\
\text { g/day }\end{array}$} & \multirow{2}{*}{$\begin{array}{c}\text { Final body weight } \\
\mathrm{g}\end{array}$} & \multicolumn{2}{|c|}{ Liver weight } \\
\hline & Status & Chol & & & $\mathrm{g}$ & g/100 g b.w. \\
\hline \multirow[t]{4}{*}{ Male } & $F$ & - & $21.7 \pm 1.2^{\mathrm{b}}$ & $302 \pm 6$ & $14.8 \pm 0.9$ & $4.9 \pm 0.2$ \\
\hline & $\mathrm{F}$ & + & $19.0 \pm 0.2^{\mathrm{c}}$ & $290 \pm 3$ & $14.7 \pm 0.6$ & $5.1 \pm 0.2$ \\
\hline & S-R & - & $25.1 \pm 2.2^{\mathrm{a}}$ & $292 \pm 11$ & $14.1 \pm 0.9$ & $4.8 \pm 0.3$ \\
\hline & S-R & + & $24.4 \pm 2.1^{\mathrm{a}}$ & $286 \pm 16$ & $14.7 \pm 0.6^{\mathrm{b}}$ & $5.2 \pm 0.3$ \\
\hline \multirow[t]{4}{*}{ Female } & $\mathrm{F}$ & - & $13.3 \pm 1.0^{\mathrm{b}}$ & $213 \pm 8$ & $10.2 \pm 0.5^{\mathrm{ab}}$ & $4.8 \pm 0.2$ \\
\hline & $\mathrm{F}$ & + & $14.0 \pm 0.9^{b}$ & $223 \pm 11$ & $11.3 \pm 0.8$ & $5.1 \pm 0.2$ \\
\hline & S-R & - & $16.7 \pm 1.2^{\mathrm{a}}$ & $214 \pm 10$ & $10.2 \pm 1.7^{\mathrm{b}}$ & $4.8 \pm 0.8$ \\
\hline & S-R & + & $17.7 \pm 0.6^{\mathrm{a}}$ & $223 \pm 10$ & $12.4 \pm 0.9^{\mathrm{a}}$ & $5.4 \pm 0.2$ \\
\hline
\end{tabular}

Values are means \pm SD for 5 rats. Means with different superscripts within a column are significantly different at $\mathrm{p}<0.05$. F, feeding; S-R, starvation-refeeding; Chol, cholesterol; TG, triacylglycerol; b.w., body weight.

Table 2 Effect of starvation-refeeding status on plasma concentrations of cholesterol and triacylglycerol in high-cholesteroldiet-fed rats.

\begin{tabular}{|c|c|c|c|c|c|c|c|c|c|}
\hline & \multicolumn{2}{|c|}{ Groups } & \multirow{2}{*}{$\begin{array}{c}\text { Total chol } \\
\mathrm{mg} / 100 \mathrm{ml}\end{array}$} & \multirow{2}{*}{$\begin{array}{l}\text { Free chol } \\
\mathrm{mg} / 100 \mathrm{ml}\end{array}$} & \multirow{2}{*}{$\begin{array}{l}\text { Chol ester } \\
\mathrm{mg} / 100 \mathrm{ml}\end{array}$} & \multirow{2}{*}{$\begin{array}{l}\text { HDL-Chol } \\
\mathrm{mg} / 100 \mathrm{ml}\end{array}$} & \multirow{2}{*}{$\begin{array}{c}\text { Non } \\
\text { HDL-Chol } \\
\mathrm{mg} / 100 \mathrm{ml}\end{array}$} & \multirow{2}{*}{$\begin{array}{c}\mathrm{TG} \\
\mathrm{mg} / 100 \mathrm{ml}\end{array}$} & \multirow{2}{*}{$\begin{array}{c}\text { Total } \\
\text { chol/TG }\end{array}$} \\
\hline & Status & Chol & & & & & & & \\
\hline \multirow[t]{4}{*}{ Male } & $\mathrm{F}$ & - & $119 \pm 7$ & $26.8 \pm 1.4^{\mathrm{ab}}$ & $93 \pm 6$ & $40.1 \pm 9.3^{b}$ & $79 \pm 15$ & $130 \pm 25$ & $0.95 \pm 0.2$ \\
\hline & $\mathrm{F}$ & + & $111 \pm 15$ & $21.4 \pm 3.9^{\mathrm{b}}$ & $90 \pm 12$ & $27.6 \pm 8.0^{\mathrm{b}}$ & $84 \pm 9$ & $150 \pm 57$ & $0.81 \pm 0.3$ \\
\hline & S-R & - & $136 \pm 14$ & $292 \pm 11$ & $104 \pm 14$ & $47.5 \pm 6.8^{\mathrm{a}}$ & $88 \pm 17$ & $109 \pm 25$ & $1.28 \pm 0.2$ \\
\hline & S-R & + & $150 \pm 28$ & $31.6 \pm 5.3^{\mathrm{a}}$ & $118 \pm 24$ & $32.0 \pm 4.8^{\mathrm{b}}$ & $117 \pm 27$ & $119 \pm 43$ & $1.35 \pm 0.4$ \\
\hline \multirow[t]{4}{*}{ Female } & $\mathrm{F}$ & - & $98 \pm 6^{\mathrm{b}}$ & $21.2 \pm 1.3^{\mathrm{b}}$ & $77 \pm 6^{\mathrm{b}}$ & $36.4 \pm 7.0^{\mathrm{a}}$ & $62 \pm 11^{\mathrm{b}}$ & $93 \pm 19$ & $1.10 \pm 0.3$ \\
\hline & $\mathrm{F}$ & + & $179 \pm 38^{\mathrm{a}}$ & $26.8 \pm 3.0^{\mathrm{ab}}$ & $153 \pm 35^{\mathrm{a}}$ & $21.1 \pm 7.9^{\mathrm{b}}$ & $158 \pm 41^{\mathrm{a}}$ & $107 \pm 10$ & $1.69 \pm 0.4$ \\
\hline & S-R & - & $113 \pm 10^{b}$ & $29.8 \pm 5.1^{\mathrm{a}}$ & $84 \pm 8^{b}$ & $43.5 \pm 9.9^{b}$ & $70 \pm 10^{b}$ & $114 \pm 49$ & $1.14 \pm 0.4$ \\
\hline & S-R & + & $180 \pm 37^{\mathrm{a}}$ & $32.7 \pm 63$ & $147 \pm 32^{\mathrm{a}}$ & $15.5 \pm 4.3^{b}$ & $164 \pm 41^{\mathrm{a}}$ & $102 \pm 25$ & $1.89 \pm 0.7$ \\
\hline
\end{tabular}

Values are means \pm SD for 5 rats. Means with different superscripts within a column are significantly different at $\mathrm{p}<0.05$. F, feeding; S-R, starvation-refeeding; Chol, cholesterol; TG, triacylglycerol.

\subsection{Liver Lipids}

Table 3 shows the liver cholesterol and TG contents. Liver total cholesterol and cholesteryl ester were significantly higher in the high-cholesterol groups than in the cholesterol-free groups in both male and female rats. Starvation-refeeding decreased liver TG content, and this difference was especially significant in the male rats. Liver free cholesterol content did not differ significantly among any of the groups.

\subsection{Fatty Acid Composition of Plasma Cholesteryl Ester}

Table 4 shows the fatty acid composition of plasma cholesteryl ester. The percentage of oleic and linoleic acids were significantly higher whereas that of arachidonic acid was significantly lower in the high-cholesterol groups than in the cholesterol-free groups in either male or female rats. Starvation-refeeding significantly increased the percentage of oleic acid in the high-cholesterol groups. In the female rats, palmitoleic acid was significantly higher and docosahexaenoic acid was significantly lower in the high-cholesterol groups regardless of the feeding status.

\section{Discussion}

In the present study, we found that starvation-refeeding increased the plasma cholesterol concentration, in particular the free cholesterol concentration (i.e., it decreased the cholesteryl ester/free cholesterol ratio), indicating that starvation-refeeding might influence the synthesis of lecithin cholesterol acyltransferase (LCAT). LCAT is present in higher concentrations in plasma than in other tissues, and mainly transfers fatty acids from the 2-position of phospholipids to cholesterol [18]. The LCAT reaction is a physiologically important source of plasma cholesteryl esters [18]. In our present findings, the high-cholesterol diet increased the plasma cholesteryl ester concentration in female rats, and decreased the plasma cholesteryl ester/free cholesterol ratio. Moreover, the percentages of oleic and linoleic acids were increased by high-cholesterol diet, whereas the percentage of arachidonic acid was decreased. These results suggest that the reaction of LCAT is influenced by the feeding status or by a high-cholesterol diet, especially in female rats. There might be substrate specificity in LCAT. 
Table 3. Effect of starvation-refeeding status on live cholesterol and triacylglycerol in high-cholesterol-diet-fed rats.

\begin{tabular}{|c|c|c|c|c|c|c|}
\hline & \multicolumn{2}{|c|}{ Groups } & \multirow{2}{*}{$\begin{array}{l}\text { Total chol } \\
\mathrm{mg} / \mathrm{g} \text { liver }\end{array}$} & \multirow{2}{*}{$\begin{array}{l}\text { Free chol } \\
\mathrm{mg} / \mathrm{g} \text { liver }\end{array}$} & \multirow{2}{*}{$\begin{array}{l}\text { Chol ester } \\
\mathrm{mg} / \mathrm{g} \text { liver }\end{array}$} & \multirow{2}{*}{$\begin{array}{c}\mathrm{TG} \\
\mathrm{mg} / \mathrm{g} \text { liver }\end{array}$} \\
\hline & Status & Chol & & & & \\
\hline \multirow[t]{4}{*}{ Male } & $F$ & - & $11.4 \pm 2.9^{b}$ & $5.90 \pm 0.5$ & $5.45 \pm 3.2^{\mathrm{b}}$ & $65 \pm 33^{\mathrm{a}}$ \\
\hline & $\mathrm{F}$ & + & $27.1 \pm 2.4^{\mathrm{a}}$ & $7.60 \pm 1.6$ & $19.5 \pm 3.4^{\mathrm{a}}$ & $73 \pm 17^{\mathrm{a}}$ \\
\hline & S-R & - & $7.39 \pm 1.8^{b}$ & $5.30 \pm 1.7$ & $2.10 \pm 0.9^{b}$ & $28 \pm 12^{\mathrm{b}}$ \\
\hline & S-R & + & $24.7 \pm 5.6^{\mathrm{a}}$ & $5.84 \pm 2.1$ & $18.8 \pm 4.5^{\mathrm{a}}$ & $36 \pm 10^{b}$ \\
\hline \multirow[t]{4}{*}{ Female } & $\mathrm{F}$ & - & $7.33 \pm 0.5^{\mathrm{b}}$ & $5.46 \pm 0.8$ & $1.87 \pm 0.8^{\mathrm{b}}$ & $25 \pm 9^{\mathrm{ab}}$ \\
\hline & $\mathrm{F}$ & + & $23.1 \pm 1.7^{\mathrm{a}}$ & $6.96 \pm 1.8$ & $16.2 \pm 1.0^{\mathrm{a}}$ & $51 \pm 26^{\mathrm{a}}$ \\
\hline & S-R & - & $6.03 \pm 1.3^{\mathrm{b}}$ & $5.15 \pm 1.4$ & $0.88 \pm 0.3^{\mathrm{b}}$ & $13 \pm 5^{\mathrm{b}}$ \\
\hline & S-R & + & $25.0 \pm 2.8^{\mathrm{a}}$ & $6.13 \pm 2.5$ & $18.9 \pm 2.5^{\mathrm{a}}$ & $32 \pm 14^{\mathrm{ab}}$ \\
\hline
\end{tabular}

Values are means \pm SD for 5 rats. Means with different superscripts within a column are significantly different at $\mathrm{p}<0.05$. F, feeding; S-R, starvation-refeeding; Chol, cholesterol; TG, triacylglycerol.

Table 4. Effect of starvation-refeeding status on fatty acid composition of plasma cholesteryl ester in high-cholesterol-diet-fed rats.

\begin{tabular}{|c|c|c|c|c|c|c|c|c|c|c|}
\hline & \multicolumn{2}{|c|}{ Groups } & \multirow{2}{*}{$\begin{array}{c}14: 0 \\
\%\end{array}$} & \multirow{2}{*}{$\begin{array}{c}16: 0 \\
\%\end{array}$} & \multirow{2}{*}{$\begin{array}{c}16: 1 \\
\%\end{array}$} & \multirow{2}{*}{$\begin{array}{c}18: 0 \\
\%\end{array}$} & \multirow{2}{*}{$\begin{array}{c}18: 1 \\
\%\end{array}$} & \multirow{2}{*}{$\begin{array}{c}18: 2 \\
\%\end{array}$} & \multirow{2}{*}{$\begin{array}{c}20: 4 \\
\%\end{array}$} & \multirow{2}{*}{$\begin{array}{c}22: 6 \\
\%\end{array}$} \\
\hline & Status & Chol & & & & & & & & \\
\hline \multirow[t]{3}{*}{ Male } & $\mathrm{F}$ & - & $0.5 \pm 0.0$ & $9.6 \pm 0.5^{\mathrm{a}}$ & $1.0 \pm 0.2$ & $1.5 \pm 0.4$ & $6.8 \pm 0.7 \mathrm{c}$ & $28.3 \pm 2.4^{b}$ & $49.4 \pm 1.9^{\mathrm{a}}$ & $1.6 \pm 0.8$ \\
\hline & S-R & - & $0.5 \pm 0.1$ & $9.9 \pm 0.6^{\mathrm{a}}$ & $1.0 \pm 0.2$ & $1.3 \pm 0.4$ & $6.9 \pm 1.1^{\mathrm{c}}$ & $27.9 \pm 1.8^{\mathrm{a}}$ & $49.1 \pm 1.4^{\mathrm{a}}$ & $1.7 \pm 0.3$ \\
\hline & S-R & + & $0.1 \pm 0.1$ & $9.2 \pm 1.7^{\mathrm{a}}$ & $1.6 \pm 0.6$ & $1.0 \pm 0.2$ & $24.2 \pm 3.5^{\mathrm{a}}$ & $31.5 \pm 1.7^{\mathrm{b}}$ & $29.5 \pm 4.2^{\mathrm{b}}$ & $1.3 \pm 0.6$ \\
\hline \multirow[t]{4}{*}{ Female } & $\mathrm{F}$ & - & $0.5 \pm 0.1$ & $7.1 \pm 0.3^{b}$ & $1.1 \pm 0.5^{\mathrm{c}}$ & $2.3 \pm 1.4$ & $7.0 \pm 0.5^{\mathrm{c}}$ & $21.4 \pm 1.7^{\mathrm{b}}$ & $54.4 \pm 3.9^{b}$ & $2.0 \pm 0.4^{\mathrm{ab}}$ \\
\hline & $\mathrm{F}$ & + & $0.2 \pm 0.1$ & $7.1 \pm 0.7^{b}$ & $2.2 \pm 0.7^{\mathrm{b}}$ & $1.2 \pm 0.2$ & $35.4 \pm 4.2^{\mathrm{b}}$ & $30.6 \pm 2.0^{\mathrm{a}}$ & $19.4 \pm 5.9^{c}$ & $0.7 \pm 0.2^{\mathrm{b}}$ \\
\hline & S-R & - & $0.2 \pm 0.1$ & $7.1 \pm 0.7^{b}$ & $0.7 \pm 0.2^{\mathrm{c}}$ & $1.4 \pm 0.4$ & $5.0 \pm 0.7^{\mathrm{c}}$ & $20.7 \pm 4.0^{\mathrm{b}}$ & $60.5 \pm 4.1^{\mathrm{a}}$ & $2.3 \pm 0.9^{\mathrm{a}}$ \\
\hline & S-R & + & $0.2 \pm 0.1$ & $7.2 \pm 0.5^{\mathrm{a}}$ & $2.8 \pm 0.6^{\mathrm{a}}$ & $1.0 \pm 0.3$ & $39.3 \pm 3.8^{\mathrm{a}}$ & $31.4 \pm 0.9^{\mathrm{a}}$ & $15.0 \pm 4.1^{\mathrm{c}}$ & $0.4 \pm 0.3^{\mathrm{b}}$ \\
\hline
\end{tabular}

Values are means $\pm \mathrm{SD}$ for 5 rats. Means with different superscripts within a column are significantly different at $\mathrm{p}<0.05$. F, feeding; S-R, starvation-refeeding.

The high-cholesterol diet decreased the plasma HDLcholesterol concentration and increased the plasma non HDL-cholesterol concentration, indicating that a highcholesterol diet facilitates the transfer of cholesteryl ester from HDL to other lipoproteins by means of the cholesteryl ester transfer protein [19]. This result supports previous findings.

Ultimately, cholesterol must enter the liver and be excreted in the bile acids [20,21]. Approximately half of the cholesterol fed or synthesized is excreted in the feces after being conversed to bile acids. Much of the cholesterol secreted in the bile is reabsorbed, and it is believed that at least some of the cholesterol that serves as a precursor for the fecal sterols is derived from the intestinal mucosa. A large fraction of the bile salts excreted is reabsorbed into the portal circulation, taken up by the liver, and re-excreted in the bile, a cycle known as enterohepatic circulation [22,23]. Unfortunately, in our experiment we did not determine the fecal excretions of cholesterol and bile salts: therefore, the effects of starvation-refeeding and high-cholesterol diets on fecal excretion or the enterohepatic circulation of cholesterol are not known. However, since the liver total cholesterol content increased 3-4 times as a result of the high-cholesterol diet, it is likely that the liver acts as a buffer for the plasma cholesterol concentration.

Many researchers have reported that starvation-refeeding increased hepatic lipogenesis [8-10]. However, in this experiment, starvation-refeeding decreased the liver TG content regardless of dietary cholesterol. No significant difference was found among the groups in the plasma TG concentration. The cause of these unexpected results is not clear. In our experiment, the rats were fed high-fat (20\% w/w corn oil) diets. The process of lipogenesis is concerned with the conversion of surplus glucose and intermediates such as pyruvate, lactate, and acetyl-CoA to fat, which constitutes the anabolic phase of this cycle $[24,25]$. The nutritional status of the organism is the main factor regulating the rate of lipogenesis. Thus, the rate is higher in well-fed animals whose diet contains a high proportion of carbohydrate. It is depressed under conditions of restricted caloric intake or a high-fat diet, particularly a diet high in unsaturated fatty acids [26]. It may be necessary to consider the quantity and composition of the dietary fat in future studies. The present study suggests that the starvation-refeeding affected the cholesterol metabolism at least in part, but a further detailed study is required to confirm and clarify the mechanism. 


\section{REFERENCES}

[1] L. Siculella, S. Sabetta, R. di Summa, M. Leo, A. M. Giudetti, F. Palmieri and G. V. Gnoni, "Starvation-induced Posttranscriptional Control of Rat Liver Mitochondrial Citrate Carrier Expression," Biochemistry Biophysics Research Communication, Vol. 299, No. 12, 2002, pp. 418-423. doi:10.1016/S0006-291X(02)02666-9

[2] S. J. Wakil and J. K. Stoops, "Structure and Metabolism of Fatty Acid Synthetase," The Enzymes, Vol. 16, No. 1, 1983, pp. 3-61. doi:10.1016/S1874-6047(08)60299-1

[3] A. G. Goodridge, "Dietary Regulation of Gene Expression: Enzymes Involved in Carbohydrate and Lipid Metabolism," Annual Review of Nutrition, Vol. 7, No. 1, 1987, pp. 157-185.

doi:10.1146/annurev.nu.07.070187.001105

[4] H. G. Guderley, D. Lapointe, M. Bedard and J. Dutil, "Metabolic Priorities during Starvation: Enzyme Sparing in Liver and White Muscle of Atlantic Cod, Gadus Morhua L.," Comparative Biochemistry and Physiology. Part A, Molecular \& Integrative Physiology, Vol. 135, No.2, 2003, pp. 347-356. doi:10.1016/S1095-6433(03)00089-8

[5] S. Awad, D. Constantin-Teodosiu, I. A. Macdonald and D. N. Lobo, "Short-term Starvation and Mitochondrial Dysfunction-A Possible Mechanism Leading to Postoperative Insulin Resistance," Clinical Nutrition, Vol. 28, No. 5, 2009, pp. 497-509. doi:10.1016/j.clnu.2009.04.014

[6] V. Longo, M. Ingelman-Sundberg, G. Amato, A. Salvetti and P. G. Gervasi, "Effect of Starvation and Chlormethiazole on Sytochrome P450s of Rat Nasal Mucosa," Biochemical Pharmacology, Vol. 59, No. 11, 2000, pp. 1425-1432. doi:10.1016/S0006-2952(00)00266-5

[7] R. T. Schimke, "Differential Effect of Fasting and Protein-free Diets on Levels of Urea Cycle Enzymes in Rat Liver," Journal of Biological Chemistry, Vol. 237, No. 6, 1962, pp. 1921-1927.

[8] B. Szepsi and C. D. Bender, "Time Course of the Starve-refeed Response in Rats; the Possible Role of Insulin," Journal of Nutrition, Vol. 101, No. 11, 1971, pp. 1563-1574.

[9] R. Wurdeman, C. D. Berdanier and R. B. Tobin, "Enzyme Overshoot in Starved-refed Rats: Role of the Adrenal Glucocorticoid," Journal of Nutrition, Vol. 108, No. 9, 1978, pp. 1457-1461.

[10] C. D. Berdanier and D. Shubeck, "Interaction of Glucocorticoid and Insulin in the Responses of Rats to Starvation-refeeding," Journal of Nutrition, Vol. 109, No. 10, pp. 1766-1771.

[11] G. H. Rothblat and D. Kritchevsky, "The Metabolism of Free and Esterified Cholesterol in Tissue Culture Cells: A Review," Experimental and Molecular Pathology, Vol. 8, No. 3, 1986, pp. 314-329.

[12] C. R. Pullinger and G. F. Gibbons, "Effects of Hormones and Pyruvate on the Rates of Secretion of Very-low-density Lipoprotein Triacylglycerol and Cholesterol by Rat Hepatocytes," Biochimica et Biophysica Acta, Vol. 833, No. 1, 1985, pp. 44-51.
[13] Q. R. Rogers and A. E. Harper, "Amino Acid Diets and Maximal Growth in the Rat," Journal of Nutrition, Vol. 87, No. 3, 1965, pp. 267-273.

[14] J. Folch, M. Lees and G. H. Sloane-Standley, "A Simple Method for the Isolation and Purification of Total Lipids from Animal Tissues," Journal of Biological Chemistry, Vol. 226, No. 1, 1957, pp. 497-509.

[15] B. Zak, "Simple Rapid Microtechnic for Serum Total Cholesterol," American Journal of Clinical Pathology, Vol. 27, No. 5, 1957, pp. 583-588.

[16] B. E. Cham, J. J. Hurwood, B. R. Knowles and L. W. Powell, "Rapid, Sensitive Method for the Separation of Free Cholesterol from Ester Cholesterol," Clinica Chimica Acta, Vol. 49, No. 1, 1973, pp. 109-113. doi:10.1016/0009-8981(73)90350-1

[17] C. Alling, L. Svennerholm and J. Tichy, "Fatty Acid Composition of Serum Cholesteryl Ester Fractions is Isolated by Thin-layer Chromatography," Journal of Chromatography, Vol. 34, No. 3, 1968, pp. 413-415. doi:10.1016/0021-9673(68)80080-9

[18] J. A. Glomset, "The Plasma Lecithin: Cholesterol Acyltransferase Reaction," Journal of Lipid Research, Vol. 9, No. 2, 1968, pp. 155-167.

[19] L. Lagrost, "The Role of Cholesteryl Ester Transfer Protein and Phospholipid Transfer Protein in the Remodeling of Plasma High-density Lipoproteins," Trends in Cardiovascular Medicine, Vol. 7, No. 6, 1997, pp. 218-224. doi:10.1016/S1050-1738(97)00053-4

[20] M. Yamamoto, T. Uemura, S. Nakama, M. Uemiya and A. Kumagai, "Serum HDL-cholesterol-increasing and Fatty Liver-improving Actions of Panax Ginseng in High Cholesterol Diet-fed Rats with Clinical Effect on Hyperlipidemia in Man," The American Journal of Chinese medicine, Vol. 11, No. 1-4, 1983, pp. 96-101. doi:10.1142/S0192415X83000161

[21] T. G. Cole, B. Pfleger and O. Hitchins, "Effects of High Cholesterol High Fat Diet on Plasma Lipoproteins in Familial Hypercholesterolemia," Metabolism, Vol. 34, No. 5, 1985, pp. 486-493. doi:10.1016/0026-0495(85)90216-1

[22] H. Shimizu, M. Yoshii, A. Seki, M. Une and T. Hoshita, "Hypocholesterolemic Effect of Ursodeoxycholylcysteic Acid in Hamsters Fed a High Cholesterol Diet," Journal of Pharmacobio-dynamics, Vol. 15, No. 10, 1992, pp. 573-580.

[23] J. B. Kane and R. J. Havel, "Treatment of Hyper Cholesterolemia," Annual Review of Medicine, Vol. 37, 1986, pp. 427-434. doi:10.1146/annurev.me.37.020186.002235

[24] A. G. Goodridge, R. A. Jenik, M. A. McDevitt, S. M. Morris and L. K. Winberry, "Malic Enzyme and Fatty Acid Synthase in the Uropygial Gland and Liver of Embryonic and Neonatal Ducklings. Tissue Specific Regulation of Gene Expression," Archives of Biochemistry and Biophysics, Vol. 230, No. 1, 1984, pp. 82-89. doi:10.1016/0003-9861(84)90088-2

[25] S. D. Clarke and M. Nakamura, "Fatty Acid Synthesis and Its Regulation," Encyclopedia of Biological Chemistry, Vol. 2, 2004, pp. 99-103. 
[26] H. Osmundsen and R. Hovik, " $\beta$-Oxidation of Polyunsaturated Fatty Acids," Biochemical Society Transactions,

Vol. 16, No. 3, 1988, pp. 420-426. 